\title{
PEMBENTUKAN INDEKS MUTU PENDIDIKAN (IMP) DI INDONESIA TAHUN 2018 DAN FAKTOR YANG MEMENGARUHINYA
}

\author{
(ESTABLISHMENT OF THE EDUCATION QUALITY INDEX OF INDONESIA IN 2018 AND \\ ITS AFFECTING FACTORS)
}

\section{Fenny Afifatul Awwaliyah'1, I Made Arcana²}

Politeknik Statistika STIS ${ }^{1}$

Politeknik Statistika STIS ${ }^{2}$

Jalan Otista No.64C RT.1/RW.4, Bidara Cina, Jatinegara, Jakarta Timur. Email: 16.9135@stis.ac.id ${ }^{1}, \underline{\text { arcana@stis.ac.id }^{2}}$

\begin{abstract}
ABSTRAK
Mutu pendidikan merupakan salah satu aspek yang dipertimbangkan dalam meningkatkan kualitas sumber daya manusia suatu bangsa. Mekanisme penilaian mutu pendidikan di Indonesia, khususnya pendidikan dasar dan menengah, dilakukan oleh BAN-S/M melalui proses akreditasi. Namun, realisasi penilaian yang dilakukan masih belum mencakup semua sekolah yang ada, sehingga belum dapat menggambarkan mutu pendidikan pada tingkat wilayah. Oleh karena itu, penyusunan Indeks Mutu Pendidikan (IMP) perlu dilakukan sebagai alat ukur terhadap mutu pendidikan pada setiap jenjang pendidikan maupun pada tingkat wilayah (34 provinsi di Indonesia) berdasarkan kerangka teori Kemendikbud dengan menerapkan metode rata-rata geometrik. Mutu pendidikan yang digambarkan dengan IMP berkorelasi negatif dengan ketimpangan gender yang diukur menggunakan Indeks ketimpangan Gender (IKG) dan berkorelasi positif dengan pembangunan manusia yang diukur menggunakan Indeks Pembangunan Manusia (IPM). Mutu pendidikan di Indonesia berdasarkan nilai IMP berada pada kategori sedang dengan nilai terendah untuk dimensi prasarana. Selain itu, hasil analisis regresi logistik ordinal memperlihatkan bahwa faktor sosial ekonomi yang memengaruhi IMP dengan tingkat signifikansi 10 persen, adalah persentase penduduk miskin, persentase rumah tangga dengan kepemilikan tanah/lahan, rata-rata persentase pengeluaran ruta untuk bukan makanan, persentase KRT yang memiliki ijazah minimal SMA, dan nilai IKG.
\end{abstract}

Kata kunci: mutu pendidikan, IMP, rata-rata geometrik, regresi logistik ordinal

\section{ABSTRACT}

The quality of education is one of the aspects considered in improving the quality of a nation's human resources. The mechanism for assessing the quality of education in Indonesia, especially primary and secondary education, is managed by BAN-S/M through an accreditation process. However, the realization of the assessment carried out still did not cover all existing schools, so it could not describe the quality of education at the regional level. Therefore, establishment of the Education Quality Index (EQI) needs to be conducted as a measuring tool for the quality of education at each level of education and at the regional level (34 provinces in Indonesia) based on the Kemendikbud theoretical framework by applying geometric averages method. The quality of education as described by the EQI has a negative correlation with gender inequality presented by the Gender Inequality Index (GII) and positively correlated with human development as measured by the Human Development Index (HDI). The quality of education in Indonesia based on the EQI score is in the medium category with the lowest score for the infrastructure dimension. In addition, the results of the ordinal logistic regression analysis showed that the socio-economic factors that influence the IMP with a significance level of 10 percent are the percentage of poor people, the percentage of households with land/ land ownership, the average percentage of non-food expenditure, and the percentage of $\mathrm{HH}$ with minimum high school education, and GII scores.

Keywords- quality of education, EQI, geometric mean, ordinal logistic regression 


\section{PENDAHULUAN}

Pendidikan merupakan salah satu aspek sosial yang penting dalam pembangunan suatu bangsa. Juharyanto, Rahayu, dan Ulfatin (2018) mengartikan bahwa pendidikan sebagai sektor yang menentukan mutu suatu bangsa. Hal ini diperkuat dengan tercantumnya pendidikan sebagai salah satu dari 17 tujuan dalam Sustainable Development Goals (SDGs), terutama tujuan keempat yaitu menjamin pendidikan yang inklusif dan setara secara mutu dan mendukung kesempatan belajar seumur hidup bagi semua (UCLG (United Cities and Local Governments), 2015). Selain itu, pendidikan juga tercantum dalam pembukaan Undang-Undang Dasar (UUD) 1945 alinea keempat, yaitu mencerdaskan kehidupan bangsa.

Sesuai amanat Undang-Undang Nomor 20 Tahun 2003 Pasal 5 bahwa setiap warga negara mempunyai hak yang sama untuk memperoleh pendidikan yang bermutu. Oleh karena itu, salah satu misi dari Kementerian Pendidikan dan Kebudayaan RI (Kemendikbud) adalah mewujudkan pendidikan yang bermutu. Kemendikbud mengukur mutu pendidikan melalui tiga dimensi dan enam indikator, yaitu: Dimensi Siswa (memuat indikator Angka Mengulang, Angka Putus Sekolah, dan Angka Lulusan), Dimensi Guru (memuat indikator Rasio Siswa-Guru dan Guru Layak Mengajar), serta Dimensi Prasarana Sekolah (memuat indikator Ruang Kelas Kondisi Baik).

Dalam upaya untuk menjaga mutu sekolah sebagai lembaga pendidikan di Indonesia, mekanisme penilaian akreditasi sekolah dilaksanakan oleh BAN-S/M (Badan Akreditasi Nasional Sekolah/Madrasah) meliputi delapan Standar Nasional Pendidikan (SNP) yaitu standar isi, standar proses, standar kompetensi lulusan, standar pendidik dan tenaga kependidikan, standar sarana dan prasarana, standar pengelolaan, standar pembiayaan, dan standar penilaian. Indikator yang digunakan untuk menggambarkan peningkatan mutu pendidikan dasar dan menengah adalah jumlah satuan pendidikan dasar dan menengah yang terakreditasi minimum B (Kemendikbud, 2018). Sampai Tahun 2018, BAN-S/M telah mengakreditasi sejumlah 55.717 sekolah dan madrasah, melebihi jumlah sekolah dan madrasah yang ditargetkan dalam Renstra Kemendikbud tahun 2015-2019 yaitu 54.000. Namun, capaian akreditasi minimum B untuk setiap jenjang pendidikan masih belum memenuhi target Kemendikbud periode 2015-2019, yaitu SD/MI (Sekolah Dasar/Madrasah Ibtidaiyah) sebesar 79,4 persen (target 84,2 persen), SMP/MTS (Sekolah Menengah Pertama/Madrasah Tsanawiyah) sebesar 60 persen (target 81 persen), SMA/MA (Sekolah Menengah Atas/Madrasah Aliyah) sebesar 65,3 persen (target 85 persen), dan SMK (Sekolah Menengah Kejuruan) sebesar 60,8 persen (target 65 persen).

Proses akreditasi hanya mencakup penilaian mutu pendidikan untuk sekolah yang memenuhi persyaratan akreditasi, diantaranya memiliki surat operasional sekolah dan melaksanakan kurikulum yang berlaku. Akan tetapi, lebih dari 40 persen sekolah di Indonesia masih belum memenuhi syarat tersebut sehingga pelaksanaan akreditasi masih belum merata. Pada Tahun 2018, lebih dari 50 persen realisasi pelaksanaan akreditasi masih terpusat di Provinsi Jawa Timur, Jawa Tengah, Jawa Barat, dan Sumatera Utara sehingga akreditasi belum dapat menunjukkan dan memperbandingkan capaian mutu pendidikan antar wilayah.

Untuk mengatasi permasalahan tersebut, diperlukan suatu ukuran yang dapat menggambarkan mutu pendidikan di setiap wilayah provinsi untuk setiap jenjang pendidikan yang mencakup seluruh sekolah dasar dan menengah. Indikator komposit merupakan alat ukur yang semakin diakui kegunaannya dalam membuat kebijakan dan komunikasi publik karena dapat menyampaikan informasi yang dapat digunakan sebagai ukuran kinerja (Saisana \& Cartwright, 2007).

Lebih jauh lagi, mutu pendidikan berkaitan erat dengan ketimpangan gender karena pendidikan merupakan sarana untuk membangun kesetaraan gender (Sumar, 2015) yang digambarkan dengan IKG (Indeks ketimpangan Gender) dan mencerminkan pembangunan manusia (Riani, 2006) yang diukur dengan IPM (Indeks Pembangunan Manusia). Mutu pendidikan juga dipengaruhi oleh faktor sosial ekonomi, diantaranya status ekonomi rumah tangga dan pendidikan orang tua (Saepuloh dan Suherman, 2018). Tujuan dari penelitian ini adalah membentuk indeks komposit untuk menggambarkan mutu pendidikan yang selanjutnya disebut Indeks Mutu Pendidikan (IMP) dan mengkaji faktor-faktor yang memengaruhinya. 


\section{METODE}

\subsection{LANDASAN TEORI Mutu Pendidikan}

Mutu secara harfiah memiliki makna sebagai ukuran baik dan buruk sesuatu hal atau benda (KBBI, 2016). Visi dari Kemendikbud adalah "Terbentuknya Insan serta Ekosistem Pendidikan dan Kebudayaan yang Berkarakter dengan Berlandaskan Gotong Royong" yang salah satu misinya yaitu "Mewujudkan Pendidikan yang Bermutu". Dalam misi tersebut, mutu pendidikan mencakup mutu siswa, guru, dan prasarana yang diukur dengan beberapa indikator, dimana masing-masing dari indikator tersebut tercakup dalam SNP. Secara rinci dijabarkan sebagai berikut:

1. Mutu Siswa yang merupakan mutu pendidikan yang diukur dari komponen siswa terdiri dari tiga indikator, yaitu :

a. Angka Mengulang, yang diukur dari proporsi siswa yang terdaftar pada suatu tingkat kelas di tahun tertentu dan menduduki kelas yang sama di tahun berikutnya. Angka Mengulang merupakan indikator yang tercakup dalam Standar Penilaian Pendidikan dan Standar Proses.

b. Angka Lulusan pada setiap jenjang pendidikan

Angka Lulusan SD merupakan proporsi siswa yang lulus SD di tahun tertentu terhadap siswa Kelas VI pada tahun sebelumnya, Angka Lulusan SMP adalah proporsi siswa yang lulus SMP di tahun tertentu terhadap siswa Kelas IX pada tahun sebelumnya, dan Angka Lulusan SMA/SMK adalah proporsi siswa yang lulus SMA/SMK di tahun tertentu terhadap siswa Kelas XII pada tahun sebelumnya. Angka Lulusan merupakan indikator yang tercakup dalam Standar Isi dan Standar Kompetensi Lulusan.

c. Angka Putus Sekolah, yang merupakan persentase siswa yang pada tahun ajaran saat ini tidak melanjutkan sekolah lagi sebelum lulus dari jenjang pendidikan tertentu, terhadap siswa yang pada tahun ajaran lalu masih bersekolah di jenjang pendidikan yang sama. Angka Putus Sekolah merupakan salah satu indikator yang tercakup dalam Standar Pengelolaan.

2. Mutu Guru merupakan mutu pendidikan yang diukur dari komponen guru, terdiri dari dua indikator yang tercakup dalam Standar Pendidik dan Tenaga Kependidikan, yaitu:

a. Persentase Guru Layak Mengajar, yang merupakan persentase guru (termasuk kepala sekolah) dengan minimum pendidikan S1/Diploma 4 terhadap guru seluruhnya.

b. Rasio Siswa-Guru, yang merupakan perbandingan antara jumlah siswa terhadap jumlah guru (termasuk kepala sekolah).

3. Mutu Prasarana Sekolah merupakan mutu pendidikan yang diukur berdasarkan ketersediaan sarana dan prasarana sekolah yang tercakup dalam Standar Sarana Prasarana, yaitu persentase ruang kelas dalam kondisi baik yang merupakan perbandingan ruang kelas dengan kondisi baik dan layak untuk kegiatan belajar mengajar terhadap jumlah ruang kelas seluruhnya.

Keenam indikator tersebut disusun berdasarkan pertimbangan hubungan antara aspekaspek di dalam sistem pendidikan (Kemendikbud, 2016) yang kemudian dibentuk menjadi indeks komposit yang akan dijadikan sebagai ukuran mutu pendidikan di 34 provinsi di Indonesia. Nilai indeks berkisar antara 0 hingga 1, yang bermakna jika nilai indeks mendekati 0 , maka mutu pendidikan semakin rendah, dan sebaliknya.

\section{Koefisien Korelasi Pearson}

Koefisien korelasi Pearson digunakan untuk mengetahui besarnya hubungan antara variabel $\mathrm{U}$ dan variabel $\mathrm{V}$ dengan formula seperti diuraikan pada persamaan (1). 


$$
r=\frac{N \sum_{n=1}^{N} U_{n} V_{n}-\sum_{n=1}^{N} U_{n} \sum_{n=1}^{N} V_{n}}{\sqrt{n \sum_{n=1}^{N} U_{n}^{2}-\left(\sum_{n=1}^{N} U_{n}\right)^{2}} \sqrt{n \sum_{n=1}^{N} V_{n}^{2}-\left(\sum_{n=1}^{N} V_{n}\right)^{2}}}
$$

keterangan :

$r \quad$ : koefisien korelasi pearson

$\mathrm{N} \quad$ : jumlah unit observasi

$\mathrm{U}_{\mathrm{n}} \quad$ : nilai variabel $\mathrm{U}$ ke-n

$\mathrm{V}_{\mathrm{n}} \quad$ : nilai variabel $\mathrm{V}$ ke-n

\section{Regresi Logistik Ordinal}

Regresi logistik ordinal diterapkan dalam pemodelan ketika variabel dependen berskala ordinal atau kategorik bertingkat. Model umum yang sering digunakan adalah proportional odds model, dimana model tersebut secara simultan melibatkan semua cumulative model. Proportional odds model dapat diterapkan ketika asumsi parallel lines terpenuhi, sementara model partial proportional odds atau non-proportional odds jika tidak memenuhi asumsi parallel lines. Kategori pada variabel dependen $Y$ dibagi menjadi dua kelompok kategori yang berurutan, sehingga jika variabel dependen $Y$ mempunyai J kategori, akan memiliki J-1 cara untuk melakukan pemisahan secara dikotomi. Model regresi logistik ordinal diformulasikan seperti pada persamaan (2) (Agresti, 2000).

$$
\begin{aligned}
& \operatorname{logit}[P(Y \leq j \mid \boldsymbol{x})]=\alpha_{j}+\boldsymbol{\beta}^{\prime} \boldsymbol{x} \\
& =\alpha_{j}+ \\
& \beta_{i} X_{i}+\cdots+\beta_{K} X_{K} ; j=1, \ldots, J-1 ; i=1,2, \ldots, K
\end{aligned}
$$

\subsection{RUANG LINGKUP PENELITIAN}

Unit analisis dalam penelitian ini adalah 34 provinsi di Indonesia. Jenjang pendidikan yang tercakup meliputi jenjang pendidikan yang berada di bawah naungan Kemendikbud yaitu SD, SMP, SMA, dan SMK, baik berstatus negeri maupun swasta yang telah memiliki izin operasional sekolah. Indikator pembentuk IMP terdiri dari enam indikator, yaitu Angka Mengulang, Angka Lulusan, Angka Putus Sekolah, Persentase Guru Layak Mengajar, Rasio Siswa-Guru, dan Persentase Ruang Kelas Kondisi Baik. Faktor yang diduga memengaruhi nilai IMP di suatu wilayah provinsi adalah persentase penduduk miskin, persentase rumah tangga (ruta) dengan kepemilikan tanah/lahan, rata-rata persentase pengeluaran ruta per bulan untuk bukan makanan, persentase kepala rumah tangga (KRT) berijazah minimal SMA, nilai IPM, dan nilai IKG. Data yang digunakan adalah data agregat yang bersumber dari Kemendikbud Tahun 2018 yaitu publikasi statistik SD, SMP, SMA, dan SMK, dan data SUSENAS (Survei Sosial Ekonomi Nasional) Tahun 2018 yang diselenggarakan oleh BPS, publikasi IPM dan IKG, serta publikasi statistik kesejahteraan rakyat.

\subsection{METODE ANALISIS}

Metode analisis yang digunakan adalah analisis deskriptif dan inferensia, dimana analisis deskriptif diterapkan dalam penyusunan IMP, menganalisis hubungan antara IMP dengan IPM dan IKG serta gambaran umum indikator penyusun IMP, sedangkan analisis inferensia diterapkan untuk menganalisis faktor-faktor yang memengaruhi nilai IMP di provinsi tertentu.

Tahapan pembentukan IMP dilakukan berdasarkan metode pembentukan indeks menurut Mazziotta dan Pareto (2013) sebagai berikut:

1. Normalisasi dengan metode min-max 
2. Pemberian bobot yang sama pada setiap dimensi (equal weighting), dengan pertimbangan setiap dimensi memberikan kontribusi yang sama terhadap mutu pendidikan. Bobot pada setiap indikator dihitung berdasarkan susunan optimal pada setiap dimensi melalui dua tahap, yaitu :

Tahap 1. Menentukan bobot indikator ke-a pada dimensi ke-c :

$$
\mathrm{W}_{a c}=\frac{1}{A_{c}} \quad ; a=1,2, \cdots, A_{c} ; c=1,2,3
$$

Tahap 2. Menentukan bobot terstandarisasi untuk indikator ke-a pada dimensi ke-c :

keterangan :

$$
\mathrm{SW}_{a c}=\frac{\mathrm{W}_{a c}}{\Sigma_{c=1}^{3} \Sigma_{a=1}^{A_{c}} \mathrm{~W}_{a c}}
$$

$A_{c}$ : banyaknya indikator pada dimensi ke-c

3. Agregasi :

$$
\begin{aligned}
& I M P_{m}=\sum_{c=1}^{3} \sum_{a=1}^{A_{c}}\left(\mathrm{SW}_{a c} \times \mathrm{I}_{a c}\right)_{m} ; \mathrm{m}=\mathrm{SD}, \mathrm{SMP}, \mathrm{SMA}, \mathrm{SMK} \\
& I M P_{n}=\sqrt[4]{I M P_{S D} \times I M P_{S M P} \times I M P_{S M A} \times I M P_{S M K}} \quad ; n=1,2, \cdots, 34
\end{aligned}
$$

keterangan :

$\mathrm{IMP}_{\mathrm{m}}$ : IMP untuk jenjang pendidikan $\mathrm{m}$

IMP $_{\mathrm{n}}$ : IMP untuk provinsi ke-n

4. Hubungan IMP dengan indeks yang telah ada, yaitu IMP dan IKG

Untuk memvalidasi IMP yang dibentuk, IMP dihubungkan dengan dua indeks BPS yang memiliki keterkaitan dengan pendidikan, yaitu Indeks Pembangunan Manusia (IPM) dan Indeks Ketimpangan Gender (IKG) menggunakan koefisien korelasi pearson pada Persamaan (1).

5. Kategorisasi kelompok nilai IMP

Setelah IMP terbentuk, maka dilakukan kategorisasi untuk kelompok nilai IMP berdasarkan nilai quartile (MacCallum dkk, 2002), yaitu :

Kategori tinggi : IMP $>Q_{2}+0,25 I Q R$

Kategori sedang : $Q_{2}-0.25 I Q R<\mathrm{IMP} \leq Q_{2}+0,25 I Q R$

Kategori rendah : IMP $\leq Q_{2}-0,25 I Q R$

keterangan :

$\mathrm{Q}_{1}$ : kuartil pertama dari IMP nasional

$\mathrm{Q}_{2}$ : nilai median dari IMP nasional

$\mathrm{Q}_{3}$ : kuartil ketiga dari IMP nasional

$\mathrm{IQR}$ : Interquartile Range $\left(\mathrm{Q}_{3}-\mathrm{Q}_{1}\right)$

Selanjutnya, nilai IMP hasil kategorisasi kemudian diuji menggunakan regresi logistik ordinal untuk mengkaji faktor yang memengaruhinya dengan tahapan :

1. Pembentukan model

Berdasarkan jumlah kategorinya, terbentuk dua model berdasarkan Persamaan (2), yaitu:

$$
\begin{array}{cc}
\text { Model I : } \ln [P(Y \leq 1 \mid \boldsymbol{x})] & =\alpha_{1}+\beta_{1} X_{1}+\beta_{2} X_{2}+\beta_{3} X_{3}+\beta_{4} X_{4}+\beta_{5} X_{5}+\beta_{6} X_{6} \\
\text { Model II }: \ln [P(Y \leq 2 \mid x)]=\alpha_{2}+\beta_{1} X_{1}+\beta_{2} X_{2}+\beta_{3} X_{3}+\beta_{4} X_{4}+\beta_{5} X_{5}+\beta_{6} X_{6}
\end{array}
$$

dimana:

$\mathrm{Y}=1$ menunjukkan nilai IMP kategori tinggi; $\mathrm{Y}=2$ menunjukkan nilai IMP kategori sedang

2. Uji kecocokan model berdasarkan nilai AIC (Akaike Information Criterion) dan BIC (Bayesian Information Criterion) terkecil.

3. Uji Kesejajaran Garis (Test of Parallel Lines) diterapkan untuk memeriksa pemenuhan asumsi kesejajaran nilai odds ratio. Apabila hasilnya tolak $H_{0}$, maka perlu dilanjutkan dengan uji Brant's Wald. 
4. Uji simultan dilakukan dengan tujuan menguji signifikansi secara statistik pengaruh variabel independen secara simultan terhadap nilai IMP. Pengujian ini menerapkan prosedur likelihood ratio test.

5. Uji parsial dengan menerapkan uji Wald untuk menguji keberartian masing-masing parameter dalam model secara parsial.

\section{HASIL DAN PEMBAHASAN}

\subsection{INDEKS MUTU PENDIDIKAN (IMP) DI INDONESIA TAHUN 2018}

Nilai IMP di tingkat provinsi menurut jenjang pendidikannya dikategorikan memiliki mutu pendidikan tinggi apabila IMP $>0,6714$, mutu pendidikan sedang apabila $0,647<$ IMP $\leq$ 0,6714, dan mutu pendidikan rendah apabila IMP $\leq 0,647$. Secara agregat nasional, nilai IMP Indonesia adalah 0,6617 artinya mutu pendidikan di Indonesia berada pada kategori sedang. Indikator yang menyumbang nilai tertinggi adalah angka lulusan (sebesar 0,9458), yang bermakna bahwa sekitar 95 persen siswa yang masuk pada jenjang pendidikan SD hingga SMA/SMK di Indonesia berhasil lulus tepat waktu. Indikator dengan nilai terendah adalah ruang kelas dengan kondisi baik (sebesar 0,2921), yang artinya terdapat kurang dari 30 persen ruang kelas pada sekolah di Indonesia, baik sekolah swasta maupun sekolah negeri dalam kondisi terawat dan layak digunakan untuk kegiatan belajar mengajar.

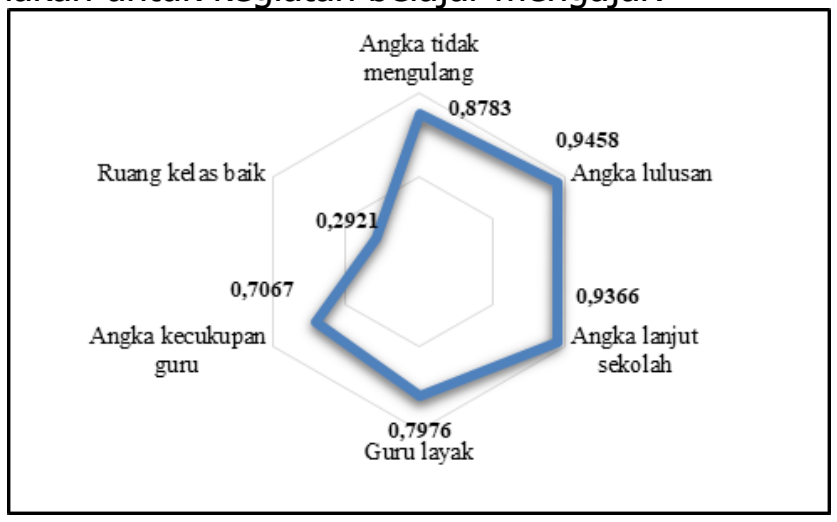

Sumber : Kemendikbud 2018 (diolah)

Gambar 1. Indikator penyusun IMP Indonesia

Nilai IMP pada setiap jenjang pendidikan mayoritas berkategori sedang, kecuali pada jenjang SMA yang berkategori tinggi (Gambar 2), dimana nilai indikator guru dan kepala sekolah yang memiliki kualifikasi akademik minimum D4/S1 sebesar 96,58 persen (Gambar 3).

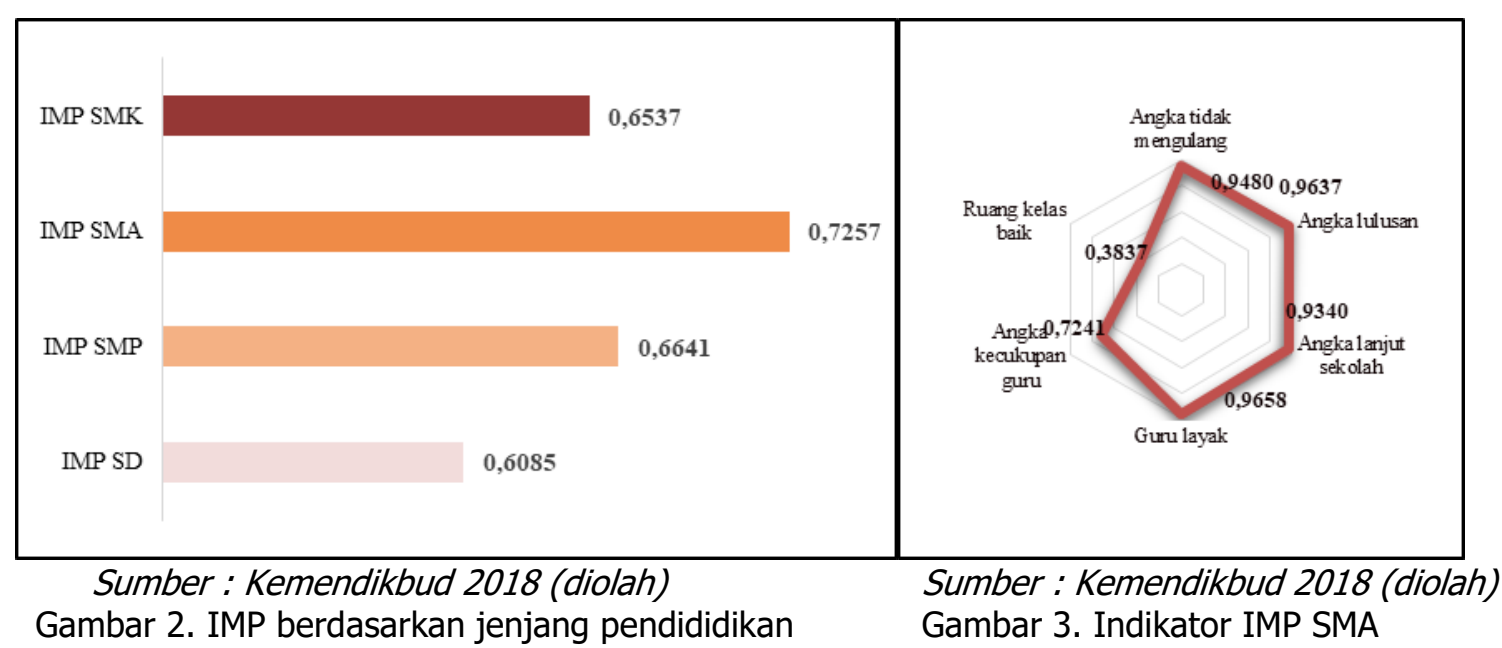




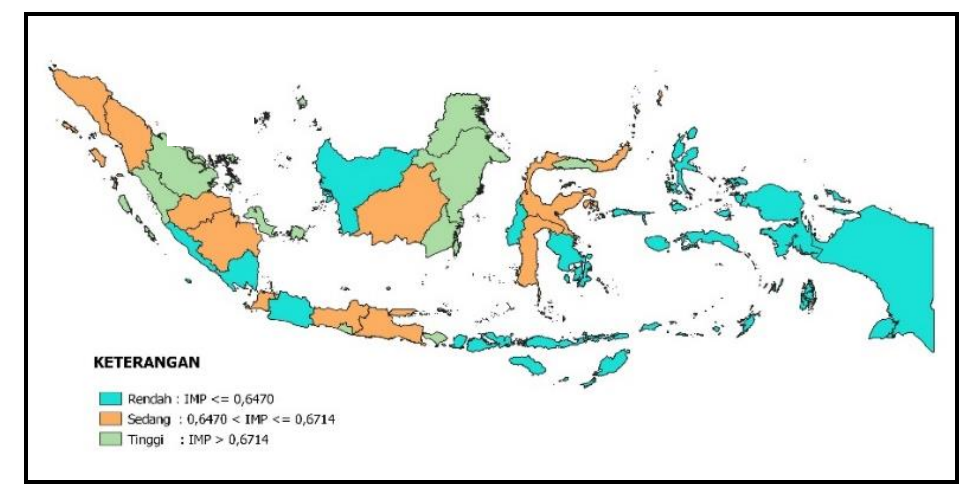

Sumber : Kemendikbud 2018(diolah)

Gambar 4. Persebaran IMP Provinsi di Indonesia

Nilai IMP pada tingkat provinsi menunjukkan bahwa sebesar 35,29 persen provinsi memiliki mutu pendidikan berkategori rendah, sedangkan sisanya berkategori tinggi dan sedang (Gambar 4). Mutu pendidikan tertinggi ditunjukkan oleh Provinsi Bali dengan IMP sebesar 0,7459, sedangkan provinsi dengan IMP terendah adalah Papua yaitu sebesar 0,4972. Gambar 5 memperlihatkan bahwa indikator penyusun IMP di Provinsi Bali dan Papua memiliki perbedaan yang paling tinggi pada indikator angka tidak mengulang, dimana di Provinsi Bali sebesar 0,9724 yang artinya persentase siswa di Provinsi Bali yang terdaftar pada suatu tingkat kelas di tahun tertentu dan menduduki kelas yang sama di tahun berikutnya kurang dari tiga persen, berbeda jauh dengan di Provinsi Papua dengan angka mengulang lebih dari 50 persen. Indikator terendah yang ditunjukkan pada kedua provinsi tersebut adalah ruang kelas dalam kondisi baik (rkb), dimana untuk ruang kelas di Provinsi Papua yang layak digunakan hanya sekitar 18 persen, sedangkan di Provinsi Bali sekitar 40 persen. Kondisi ini memperlihatkan bahwa masih kurangnya ketersediaan sarana ruang kelas yang kondisinya baik dan nyaman bagi siswa dialami oleh provinsi, dengan mutu pendidikan tinggi maupun rendah. Berdasarkan dimensi penyusunnya, dimensi yang paling besar kontribusinya terhadap IMP Provinsi Papua adalah dimensi guru, sedangkan di Provinsi Bali adalah dimensi siswa.

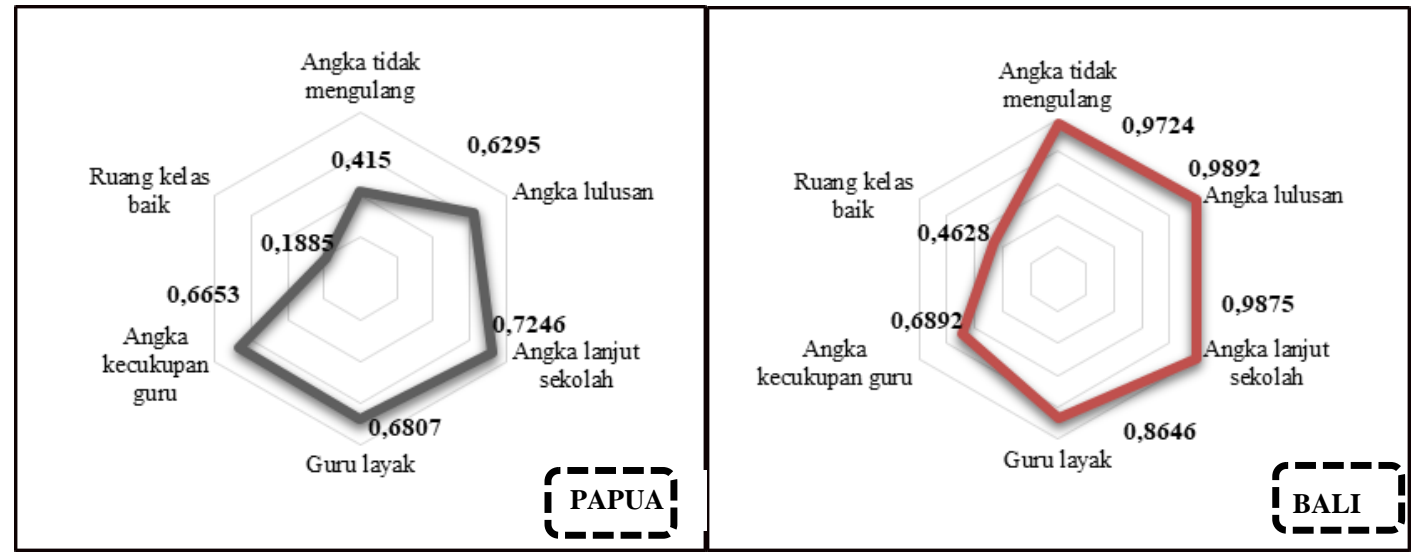

Sumber : Kemendikbud 2018 (diolah)

Gambar 5. Indikator penyusun IMP Bali dan Papua

Berdasarkan koefisien korelasi pearson (Persamaan 1) antara IMP dengan IPM dan IKG, diperoleh nilai korelasi yang ditampilkan pada Tabel 1.

Tabel 1. Nilai korelasi antara IMP dengan IPM dan IKG

No

(1)

IPM

IKG
IMP

(2)

0,771

$-0,659$
Keterangan

(3)

Korelasi cukup kuat dan positif

Korelasi cukup kuat dan negatif 
Tabel 1 memperlihatkan bahwa terdapat hubungan yang relatif kuat dan positif antara IMP dengan IPM, yang artinya semakin tinggi mutu pendidikan di suatu wilayah, maka pembangunan sumber daya manusia di wilayah tersebut akan semakin baik. Hal ini sejalan dengan hasil penelitian Riani (2006) yang menyatakan bahwa tingkat pembangunan manusia mencerminkan kondisi mutu pendidikan. Sedangkan antara IMP dengan IKG memiliki hubungan yang negatif, artinya semakin tinggi mutu pendidikan di suatu wilayah, maka ketimpangan gender akan semakin kecil. Hal ini sejalan dengan hasil penelitian Sumar (2015) dimana peningkatan mutu pendidikan merupakan sarana untuk mencapai kesetaraan gender.

Hubungan antara IMP dan IPM berdasarkan analisis kuadran (Gambar 6) menunjukkan bahwa mayoritas provinsi di Indonesia (38,24 persen) mengelompok di Kuadran II, yang merupakan kelompok provinsi dengan nilai IMP di atas rata-rata nasional dan nilai IPM di bawah rata-rata nasional. Kondisi ini tidak sesuai dengan pola yang terjadi dengan provinsi lainnya. Kondisi yang sama juga diperlihatkan oleh kelompok provinsi yang berada di kuadran IV, yang merupakan kelompok provinsi dengan nilai IMP di bawah rata-rata nasional dan nilai IPM di atas rata-rata nasional. Dengan demikian, terdapat sekitar 14 provinsi (41,18 persen) memiliki pola hubungan yang tidak sejalan antara tingkat mutu pendidikan dengan pembangunan sumber daya manusianya. Hal ini bisa terjadi karena dimensi penyusun IPM tidak hanya terdiri dari pendidikan, namun ada kontribusi dan pengaruh dimensi kesehatan dan standar hidup yang layak yang dapat memengaruhi nilai IPM.

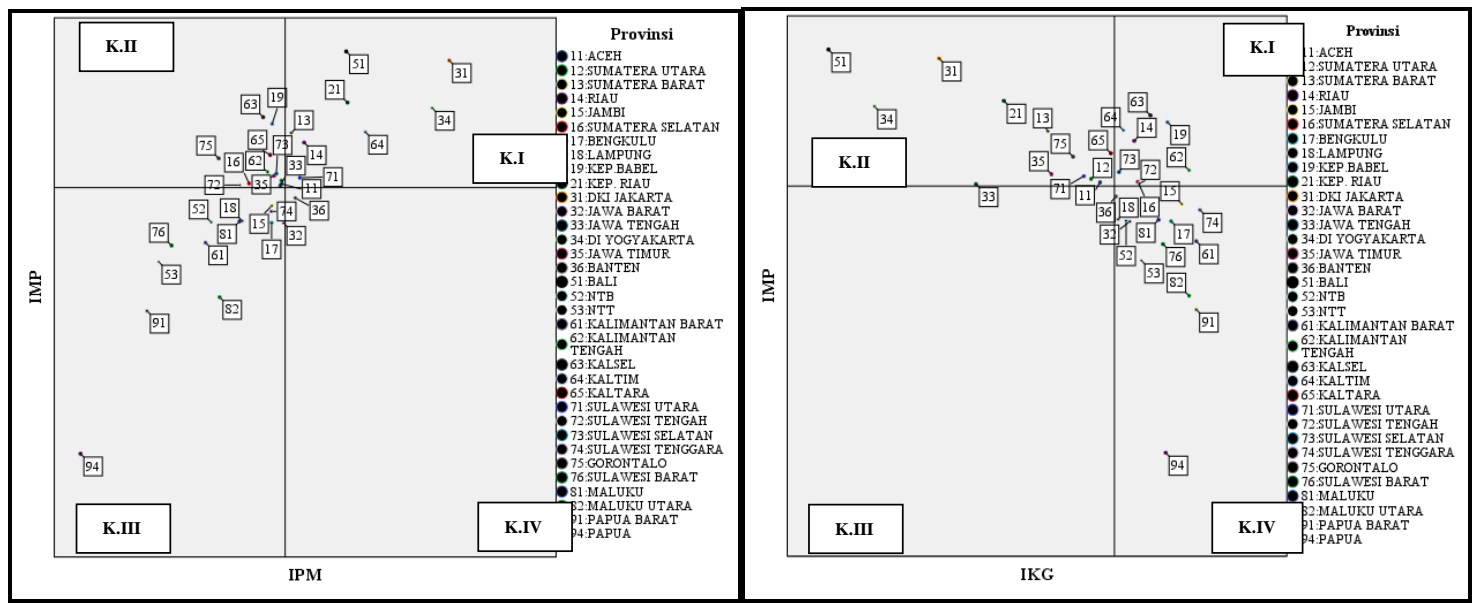

Sumber : BPS dan Kemendikbud 2018 (diolah) Sumber : BPS dan Kemendikbud 2018 (diolah) Gambar 6. Hubungan antara IMP dengan IPM Gambar 7. Hubungan antara IMP dengan IKG

Analisis kuadran untuk hubungan antara IMP dan IKG (Gambar 7) menunjukkan bahwa mayoritas provinsi di Indonesia (38,24 persen) mengelompok di Kuadran IV, yang merupakan kelompok provinsi dengan nilai IMP di bawah rata-rata nasional dan IKG di atas rata-rata nasional. Tidak terdapat provinsi yang berada di kuadran III yang merupakan kelompok provinsi dengan nilai IMP dan IKG di bawah rata-rata nasional. Hal ini memperlihatkan bahwa tidak ada provinsi yang memiliki mutu pendidikan yang relatif rendah dengan tingkat ketimpangan gender yang juga rendah. Di sisi lain, terdapat tujuh provinsi di Indonesia yang berada di kuadran I yang merupakan kelompok provinsi dengan nilai IMP dan IKG yang nilai indeksnya di atas rata-rata nasional. Hal ini kemungkinan terjadi karena kondisi sosial, budaya serta adat istiadat masyarakat yang berbeda setiap wilayah provinsi terkait hal kesetaraan gender. Selain itu, sama halnya dengan IPM, IMP yang tidak berhubungan negatif dengan IKG karena dimensi penyusun IKG tidak hanya terdiri dari pendidikan/pemberdayaan, namun ada kontribusi dan pengaruh dimensi kesehatan wanita dan tingkat partisipasi angkatan kerja (TPAK) yang dapat memengaruhi nilai IKG.

\subsection{FAKTOR-FAKTOR YANG MEMENGARUHI IMP}


Berdasarkan AIC dan BIC yang diperoleh, maka model regresi logistik ordinal menggunakan pendekatan model proportional odds dengan nilai terkecil yaitu masing-masing sebesar 54,9493 dan 67,1602 adalah:

Model I :

Logit $[\mathrm{P}(\mathrm{Y} \leq 1)]=2,916-0,261$

$X_{1}^{*}-0,112 X_{2}^{*}+0,537 X_{3}^{*}+2,526 X_{4}^{*}-2,061 X_{5}+2,733 X_{6}^{*}$

Model II :

Logit $[\mathrm{P}(\mathrm{Y} \leq 2)]=6,299-0,261$

$X_{1}^{*}-0,112 X_{2}^{*}+0,537 X_{3}^{*}+2,526 X_{4}^{*}-2,061 X_{5}+2,733 X_{6}^{*}$

$*$ : signifikan pada $\alpha=0,1$

Model I dan model II memenuhi asumsi parallel lines pada tingkat signifikansi sebesar 10 persen yang menunjukkan bahwa model proportional odds dapat diterapkan, dimana koefisien regresi pada kedua model tersebut adalah sama/parallel. Pegujian secara simultan terhadap koefisien regresinya pada tingkat signifikansi sebesar 10 persen memperlihatkan bahwa terdapat minimal satu variabel independen yang berpengaruh terhadap IMP. Selanjutnya, dengan menerapkan pengujian secara parsial diperoleh hasil bahwa pada tingkat signifikansi sebesar 10 persen, lima dari enam variabel independen pada model berpengaruh signifikan terhadap IMP, yaitu persentase penduduk miskin $\left(\mathrm{X}_{1}\right)$, persentase ruta dengan kepemilikan tanah/lahan $\left(\mathrm{X}_{2}\right)$, rata-rata persentase pengeluaran ruta untuk bukan makanan di wilayah tertentu $\left(\mathrm{X}_{3}\right)$, persentase KRT dengan ijazah minimal SMA $\left(\mathrm{X}_{4}\right)$, dan $\operatorname{IKG}\left(\mathrm{X}_{6}\right)$.

Persentase penduduk miskin $\left(\mathrm{X}_{1}\right)$ dengan nilai koefisien yang negatif dan nilai odds ratio sebesar 0,77 (=exp $(-0,261)$ ) mengandung makna bahwa provinsi yang peningkatan persentase penduduk miskinnya sebesar 1 persen memiliki kecenderungan untuk menurunkan tingkat mutu pendidikan sebesar 0,23 kali, baik mutu pendidikan tinggi dibandingkan minimal sedang (model I) maupun untuk mutu pendidikan maksimal sedang dibandingkan rendah (model II) pada saat variabel independen lainnya konstan. Hasil penelitian ini sejalan dengan penelitian Ramadhany (2019) yang menyatakan bahwa semakin banyak penduduk miskin di suatu wilayah maka akan menyebabkan ketimpangan pendidikan semakin besar.

Persentase ruta dengan kepemilikan tanah/lahan $\left(\mathrm{X}_{2}\right)$ dengan nilai koefisien yang negatif dan odds ratio sebesar $0,894(=\exp (-0,112))$ yang menunjukkan bahwa provinsi dengan peningkatan persentase ruta dengan kepemilikan tanah/lahan sebesar 1 persen memiliki kecenderungan menurunkan tingkat mutu pendidikan sebesar 0,11 kali, baik untuk mutu pendidikan tinggi dibandingkan minimal sedang (model I) maupun untuk mutu pendidikan maksimal sedang dibandingkan rendah (model II) pada saat variabel independen lainnya konstan.

Rata-rata persentase pengeluaran ruta untuk bukan makanan $\left(\mathrm{X}_{3}\right)$ dengan nilai koefisien yang positif dan odds ratio sebesar 1,711 (=exp $(0,537)$ ) menggambarkan bahwa provinsi dengan peningkatan rata-rata persentase pengeluaran bukan makanan sebesar 1 persen mempunyai kecenderungan dapat meningkatkan mutu pendidikan di wilayahnya sebesar 1,711 kali, baik untuk mutu pendidikan tinggi dibandingkan minimal sedang (model I) maupun untuk mutu pendidikan maksimal sedang dibandingkan rendah (model II) pada saat variabel independen lainnya konstan. Biaya pendidikan termasuk dalam pengeluaran bukan makanan, sehingga dapat dikatakan bahwa meningkatnya biaya pendidikan merupakan salah satu diantara banyak faktor penentu pendidikan yang dapat meningkatkan mutu pendidikan yaitu berfungsi dalam proses belajar mengajar. Hasil dari penelitian ini sejalan dengan penelitian Pratama dan Sutopo (2015) yang menghasilkan kesimpulan bahwa biaya pendidikan berpengaruh positif terhadap mutu pendidikan.

Persentase KRT berijazah minimal SMA $\left(\mathrm{X}_{4}\right)$ dengan nilai koefisien yang positif dan odds ratio sebesar 12,503 (=exp $(2,526)$ ) memperlhatkan bahwa provinsi dengan persentase KRT yang memiliki pendidikan minimal SMA yang relatif tinggi mempunyai kecenderungan 12,503 kali (dibandingkan wilayah provinsi dengan persentase KRT berpendidikan minimal SMA yang 
relatif rendah), baik untuk mutu pendidikan tinggi dibandingkan minimal sedang (model I) maupun untuk memiliki mutu pendidikan maksimal sedang dibandingkan rendah (model II) pada saat variabel independen lainnya konstan. Hal ini sejalan dengan hasil penelitian oleh Ghifari (2019) yang menyatakan bahwa semakin tinggi pendidikan KRT di suatu provinsi akan menurunkan ketimpangan pendidikan di wilayah tersebut dikarenakan KRT yang mencapai pendidikan pada jenjang tertentu cenderung menginginkan anaknya untuk minimal berpendidikan yang sama seperti dirinya.

Nilai IKG dengan koefisien regresi positif dan odds ratio sebesar $15,383(=\exp (2,733))$ menunjukkan bahwa provinsi dengan nilai ketimpangan gender yang rendah memilki kecenderungan untuk meningkatkan mutu pendidikan sebesar 15,383 kali (dibandingkan provinsi dengan nilai ketimpangan gender di atas rata-rata nasional), baik untuk mutu pendidikan tinggi dibandingkan minimal sedang (model I) maupun untuk mutu pendidikan maksimal sedang dibandingkan rendah (model II) pada saat variabel independen lainnya konstan. Hal ini sejalan dengan penelitian Sumar (2015) bahwa pendidikan merupakan salah satu aspek sosial untuk mencapai kesetaraan gender.

\section{KESIMPULAN}

Berdasarkan hasil analisis deskriptif untuk capaian nilai IMP pada setiap provinsi di Indonesia serta hasil penerapan model regresi logistik ordinal yang telah diuraikan pada bab sebelumnya, maka kesimpulan yang diperoleh adalah :

1. Gambaran mutu pendidikan berdasarkan nilai IMP memperlihatkan bahwa tingkat mutu pendidikan di Indonesia termasuk pada kategori sedang $(0,6617)$, dimana Dimensi Prasarana Sekolah memiliki nilai terendah, yaitu kurang dari sepertiga (29,21 persen) ruang kelas yang tersedia dalam kondisi baik dan layak untuk kegiatan belajar mengajar. Berdasarkan jenjang pendidikannya, mutu pendidikan tertinggi terlihat pada jenjang SMA $(0,7257)$. Di tingkat provinsi, mutu pendidikan yang tertinggi adalah Provinsi Bali $(0,7459)$ dan yang terendah adalah Provinsi Papua $(0,4972)$.

2. Terdapat lima dari enam faktor yang digunakan dalam penelitian ini memiliki pengaruh signifikan terhadap nilai IMP. Faktor dengan pengaruh positif ditunjukkan oleh rata-rata persentase pengeluaran ruta untuk bukan makanan, persentase KRT berijazah minimal SMA, dan IKG. Sedangkan faktor dengan pengaruh negatif adalah persentase penduduk miskin dan persentase ruta dengan kepemilikan tanah/lahan. Dari kelima variabel yang signifikan tersebut, nilai IKG memiliki pengaruh paling besar terhadap IMP dengan odds ratio sebesar 15,383 .

\section{DAFTAR PUSTAKA}

Agresti, A. (2000). Categorical Data Analysis (2 ${ }^{\text {nd }}$ edition). New Yok: John Wiley \& Sons.

Astuti, W.Y.(2016). Pengaruh Kondisi Sosial Ekonomi Keluarga Terhadap Minat Belajar Siswa SMK YPKK 3 Sleman. Jurnal Pendidikan dan Ekonomi, 5(4),310.

Badan Pusat Statistik. (2018). Indikator Kesejahteraan Rakyat 2018. Jakarta: Badan Pusat Statistik.

Badan Pusat Statistik. (2018). Statistik Penunjang Pendidikan 2018. Jakarta: Badan Pusat Statistik.

BAN-S/M. (2018). Capaian Dan Analisis Pemenuhan Standar Nasional Pendidikan (SNP) Hasil Akreditasi Sekolah Dan Madrasah Tahun 2018. Jakarta: BAN-S//M.

Cartwright, M. S. (2007). Measuring Lifelong Learning and its impact on Happiness-The Canadian paradigm. International Conference on Policies for Happines. Diakses pada $\begin{array}{lllll}\text { tanggal } & 11 & \text { Februari } 2020 \quad \text { melalui }\end{array}$ "https://www.researchgate.net/publication/238779562_Measuring_Lifelong_Learning_and_i ts_impact_on_Happiness_The_Canadian_paradigm" 
https://www.researchgate.net/publication/238779562 Measuring Lifelong Learning and it s impact on Happiness The Canadian paradigm

Ghifari, U. M. (2019). Determinan Ketimpangan Pendidikan di Indonesia dengan Pendekatan Spatial Lag of $X$ [Skripsi]. Jakarta : Politeknik Statistika STIS.

Juharyanto, Rahayu, dan Ulfatin (2018). Sistem Pengelolaan Guru Tidak Tetap (GTT) dalam Peningkatan Mutu Pendidikan. Jurnal Adminitrasi dan Manajemen Pendidikan, 1(3), 263.

Kementerian Pendidikan dan Kebudayaan. (2016). Indikator Pendidikan 2015/2016. Jakarta: Kementerian Pendidikan dan Kebudayaan.

Kementerian Pendidikan dan Kebudayaan. (2016). KBBI Daring. Diakses pada tanggal 5 Januari 2020 melalui HYPERLINK "https://kbbi.kemdikbud.go.id/" https://kbbi.kemdikbud.go.id/

Kurniawan, Robert \& Sugiarto. (2017). Pemetaan Indeks Pembangunan Pendidikan Tahun 2015.

MacCallum Robert C et al.(2002). On The Practice of dichotomization of Quantitative Variables. Psycological Methods, 1(7),19. Diakses pada tanggal 10 Februari 2020 melalui HYPERLINK "http://www.psychology.sunysb.edu/attachment/measures/content/maccallum_on_dichoto mizing.pdf"

http://www.psychology.sunysb.edu/attachment/measures/content/maccallum on dichotom izing.pdf

Mazziotta, M., \& Pareto, A. (2013). Methods for constructing composite indices: One for all or all for one. Rivista Italiana di Economia Demografia e Statistica, 67(2), 67-80. 04 Januari 2020. HYPERLINK "https://www.researchgate.net/profile/Adriano_Pareto/Publication/281106596_Methods_for _Constructing_Composite_Indices_One_for_All_or_All_for_One/links/55d5b16708aeb38e8a 7fc2bf/Methods-for-Constructing-Composite-Indices-One-for-All-or-All-for-One.pdf" https://www.researchgate.net/profile/Adriano Pareto/Publication/281106596 Methods for Construc ting Composite Indices One for All or All for One/links/55d5b16708aeb38e8a7fc2bf/Methodsfor-Constructing-Composite-Indices-One-for-All-or-All-for-One.pdf

BIBLIOGRAPHY Pratama dan Sutopo (2015). The Classification on provinces in Indonesia Based on the Education Quality Index and The Factors Which Affect it in 2012. Prosiding Simposium Nasional Riset Pendidikan II Tahun 2015. Universitas Paramadina, Jakarta.

Ramadhany, F. D. (2019). Ketimpangan Pendidikan dan Determinannya di Kabupaten/Kota Provinsi Sumatera Utara Tahun 2017[Skripsi]. Jakarta : Politeknik Statistika STIS.

Riani, W. (2006). Pembangunan Pendidikan Sebagai Motor Penggerak IPM Jawa Barat. 22(3), (278).

Saisana \& Cartwright (2007). Measuring Lifelong Learning and its impact on Happiness-The Canadian paradigm. International Conference on Policies for Happines.11 Februari 2020. HYPERLINK

"https://www.researchgate.net/publication/238779562_Measuring_Lifelong_Learning_an d_its_impact_on_Happiness_The_Canadian_paradigm" https://www.researchgate.net/publication/238779562 Measuring Lifelong Learning an d its impact on Happiness The Canadian paradigm

Sumar, W. T. (2015). Implementasi Kesetaraan Gender dalam Bidang Pendidikan. MUSAWA, $7(1), 179$.

UCLG (United Cities and Local Governments). (2015). In Tujuan SDGs. Jakarta: UCLG 
Seminar Nasional Official Statistics 2019: Pengembangan Official Statistics dalam mendukung Implementasi SDG's 